\title{
The impact of edge effect on termite community (Blattodea: Isoptera) in fragments of Brazilian Atlantic Rainforest
}

\author{
C. S. Almeida ${ }^{a, b}$, P. F. Cristaldo ${ }^{b}$, D. F. Florencio ${ }^{c}$, E. J. M. Ribeiro ${ }^{b}$, N. G. Cruz ${ }^{a, b}$, E. A. Silva ${ }^{\text {, }}$ \\ D. A. Costa and A. P. A. Araújo $^{b *}$
}

aPrograma de Pós-graduação em Ecologia e Conservação, Universidade Federal de Sergipe - UFS, Av. Marechal Rondon, s/n, Jardim Rosa Elze, CEP 49100-000, São Cristóvão, SE, Brazil

'Laboratório de Interações Ecológicas, Departamento de Ecologia, Universidade Federal de Sergipe - UFS, Av. Marechal Rondon, s/n, Jardim Rosa Elze, CEP 49100-000, São Cristóvão, SE, Brazil

'Departamento de Agrotecnologia e Ciências Sociais, Universidade Federal Rural do Semi-Árido - UFERSA, BR 110, Km 47, Bairro Pres. Costa e Silva, CP 137, CEP 59625-900, Mossoró, RN, Brazil

dPrograma de Pós-graduação em Ciências Ambientais, Universidade Federal de Rondônia - UNIR, Av. Norte Sul, 7300, Bairro Nova Morada, CEP 76940-000, Rolim de Moura, RO, Brazil

'Departamento de Ciências Biológicas, Universidade do Estado de Mato Grosso - UNEMAT, Rod. MT. 358, Km 07, Jd. Aeroporto, CEP 78300-000, Tangará da Serra, MT, Brazil

*e-mail: anatermes@gmail.com

Received: October 29, 2015 - Accepted: April 13, 2016 - Distributed: August 31, 2017

(With 1 figure)

\begin{abstract}
Habitat fragmentation is considered to be one of the biggest threats to tropical ecosystem functioning. In this region, termites perform an important ecological role as decomposers and ecosystem engineers. In the present study, we tested whether termite community is negatively affected by edge effects on three fragments of Brazilian Atlantic Rainforest. Termite abundance and vegetation structure were sampled in 10 transects $(15 \times 2 \mathrm{~m})$, while termite richness, activity, and soil litter biomass were measured in 16 quadrants $(5 \times 2 \mathrm{~m})$ at forest edge and interior of each fragment. Habitat structure (i.e. number of tree, diameter at breast height and soil litter biomass) did not differ between forest edge and interior of fragments. Termite richness, abundance and activity were not affected by edge effect. However, differences were observed in the $\beta$ diversity between forest edge and interior as well as in the fragments sampled. The $\beta$ diversity partitioning indicates that species turnover is the determinant process of termite community composition under edge effect. Our results suggest that conservation strategies should be based on the selection of several distinct sites instead of few rich sites (e.g. nesting).
\end{abstract}

Keywords: $\beta$ diversity, habitat fragmentation, Termitoidea, species turnover.

\section{O impacto do efeito de borda na comunidade de cupins (Blattodea: Isoptera) em fragmentos de florestas da Mata Atlântica}

\section{Resumo}

A fragmentação do habitat é considerada uma das maiores ameaças para o funcionamento do ecossistema tropical. Nesta região, os cupins desempenham um papel ecológico importante como decompositores e engenheiros do ecossistema. No presente estudo, testamos se comunidades de cupins são negativamente afetadas pelo efeito de borda em três fragmentos de Mata Atlântica. Para isso, foram amostrados a abundância de cupins e a estrutura da vegetação em 10 transectos $(15 \times 2 \mathrm{~m})$, enquanto a riqueza, abundância de cupins e biomassa da serrapilheira foram amostrados em 16 parcelas $(5 \times 2 \mathrm{~m})$ na borda e no interior de cada um dos três fragmentos. A estrutura do habitat (número de árvores, diâmetro à altura do peito e biomassa da serrapilheira) não diferiu entre a borda e o interior dos fragmentos. A riqueza, abundância e atividade dos cupins também não foram afetados pelo efeito de borda. No entanto, foram observadas diferenças na diversidade $\beta$ entre borda e interior dos fragmentos, bem como nos fragmentos amostrados. O particionamento da diversidade $\beta$ indicou que a substituição de espécies ("turnover") é o processo determinante da composição da comunidade de cupins sob efeito de borda. Nossos resultados sugerem que as estratégias de conservação devem ser baseadas na seleção de locais distintos em vez de poucos locais (via processo de aninhamento - "nesting").

Palavras-chave: diversidade $\beta$, fragmentação de habitat, Termitoidea, substituição de espécies (turnover). 


\section{Introduction}

Habitat fragmentation is one of the main anthropogenic threats leading to changes in biotic communities (Leidner et al., 2010). In general, habitat fragmentation is the process in which continuous areas are subdivided in isolated and smaller remnants (Souza et al., 2001). Area reduction from habitat fragmentation enhances edge effects - characterized by an increase in the incidence of light, temperature, winds and a reduction of humidity (Laurance, 2004). This process changes vegetational structure and microclimate conditions between forest edge and interior affecting directly the communities structure of animals (e.g. Maciel et al., 2003; Laurance, 2004) as well as indirectly through changes in the activity and behaviour of predator's species. A range of distinct taxonomic group has been shown to be affected by habitat fragmentation or edge effect (Klein, 1989; Pinheiro et al., 2010; Penido et al., 2015).

The losses of species and populations have been suggested to promote a decline in the ecosystem processes with effect on a global scale (see Dirzo et al., 2014). In a long-term, effects of habitat disturbance could promote modifications in the ecosystem processes (Dambros et al., 2013). Termites are known to act directly in the ecosystem process through changes in the physical and chemical structure of soil as well as in the microbial activity and organic matter decomposition (Bignell and Eggleton, 2000; Holt and Lepage, 2000). The activity of termites on soil indirectly allows the establishment and maintenance of other species at a local scale (Redford, 1984; Pringle et al., 2010; Beaudrot et al., 2011), make them "ecosystem engineers" (see Jones et al., 1994).

Termite species have been shown to be responsive to environmental disturbance (Souza and Brown, 1994; Davies, 2002; Luke et al., 2014). However, mechanisms in which habitat fragmentation alters the community structure of these insects are still poorly studied. Termites are soft-body insects in which temperature and humid affect their distribution and diversity (Cancello et al., 2014). Thus, alteration of vegetational structure and microclimate conditions in edge areas may decrease resource availability and nesting sites promoting strong effects on termite communities. In fact, the abundance of termite nests has been shown to decrease in forest edge compared with interior (Axelsson and Andersson, 2012).

In the present study, we analyzed whether termite community is affected by the edge effects of habitat fragmentation process on three fragments of Brazilian Atlantic Rainforest - "hotspot" of global biodiversity regarded as one of the most threatened biome in the world (Myers et al., 2000; Ribeiro et al., 2009). We tested the hypotheses that $(i)$ termite richness, abundance and their activity in the sampled area have a positive relationship with vegetation structure and resource availability, (ii) such measures of termite species community decrease in the forest edge compared with interior of fragments and (iii) termite species composition ( $\beta$ diversity) is altered between forest edge and interior.

\section{Material and Methods}

\subsection{Study site}

Fieldwork was conducted on three fragments (Table 1) of Atlantic Rainforest located in the state of Sergipe, Northeastern, Brazil. The landscape consists mainly of a semi-deciduous forest with secondary remnants (Santos et al., 2007). Fragments of the Brazilian Atlantic Rainforest ("Mata Atlântica") are reported as a priority area for biodiversity conservation ("hotspot") (Myers et al., 2000 ) and an important area of endemism with only $2 \%$ of the original forest area (Silva and Tabarelli, 2000).

\subsection{Sampling design}

Termite community and habitat structure were sampled from December 2013 to January 2014 (“dry season”). In each fragment and locality (forest edge and interior) two distinct methodologies were used: $(i)$ quadrants and (ii) transect (as described below). In quadrants, sampling was performed to assess the termite richness, their activity in the sampled area and soil litter biomass. In transects, sampling was carried out to assess the termite abundance and vegetational structure.

Forest edge sites were delimited up to $5 \mathrm{~m}$. after the begging of vegetation in all sampled fragments. Forest interior sites were $100 \mathrm{~m}$. for the smallest fragment (Mata do Campus Rural - MCR) and $150 \mathrm{~m}$. for the larger ones (Mata do Crasto - MC and Mata do Junco - MJ) (Table 1).

\subsubsection{Termite community}

To examine the edge effect of habitat fragmentation on termite species richness and their activity in the area, termites were collected in 16 quadrants $(5 \mathrm{~m} \times 2 \mathrm{~m})$ in each one of the fragments (eight at the forest edge and eight at the forest interior), totalizing 48 quadrants and $480 \mathrm{~m}^{2}$ of sampled area. Each quadrant was at least $20 \mathrm{~m}$

Table 1. Overview of fragments sampled in the present study with their respective area (ha), locality and geographic coordinates.

\begin{tabular}{clclcc}
\hline Forest code & \multicolumn{1}{c}{ Forest name } & Area (ha) & \multicolumn{1}{c}{ Locality } & Latitude & Longitude \\
\hline MC & Mata do Castro & 900 & $\begin{array}{l}\text { Santa Luzia do } \\
\text { Ithanhy }\end{array}$ & $11^{\circ} 22^{\prime}$ & $37^{\circ} 25^{\prime}$ \\
\hline MJ & $\begin{array}{l}\text { Refugio da Vida } \\
\text { Silvestre Mata do Junco }\end{array}$ & 766 & Capela & $10^{\circ} 46^{\prime}$ & $37^{\circ} 01^{\prime}$ \\
\hline MCR & $\begin{array}{l}\text { Campus Rural da } \\
\text { Universidade Federal } \\
\text { de Sergipe }\end{array}$ & 1 & São Cristovão & $11^{\circ} 01^{\prime}$ & $37^{\circ} 12^{\prime}$ \\
\hline
\end{tabular}


apart from each other. Termite sampling was carried out simultaneously for two collectors during $30 \mathrm{~min}$., corresponding the sampling effort of 1 hour per collector according to protocol proposed by Jones and Eggleton (2000). All quadrant area was inspected for termite collections from nests (epigeal and arboreal) to potential resources (soil surface, litter, dead wood, trunks, galleries on the soil surface or tree trunk) as well as excavations in the soil $(12 \times 12 \times 10 \mathrm{~cm})$.

The number of termite record in each quadrant was used in the present study as an estimate of termite's activity in the area. Such measurement is a new approach and it is different from the relative abundance commonly used in studies of termite communities. The occurrence of particular species per plot, quadrants or transect is frequently used as a single record of abundance independently of how many times this species has been recorded in the sampled area (e.g. see Oliveira et al., 2013). However, regardless whether individuals collected belong to the same or different colonies, the number of records per area (plot, quadrants or transect) provide an overview of the rate of the habitat use by these individuals and therefore, how much termites contribute to ecosystem functioning in terms of nutrient cycling and soil properties. Thus, our estimate of termite activity in the area can provide a surrogate of how much termites contribute to ecosystem functioning.

To examine the edge effect of habitat fragmentation on termite abundance, epigeal and arboreal nests were quantified throughout 10 transects $(15 \mathrm{~m} \times 2 \mathrm{~m})$ in each one of the fragments (five in the forest edge and five in the forest interior), totalizing 30 transects and $900 \mathrm{~m}^{2}$ of sampled area. Only active nests with termite colony inside were used in the statistical analysis.

Termites were manually collected using entomological forceps in both transects and quadrants. Specimens collected were preserved in $80 \%$ alcohol, labelled and later identified to species (or morphospecies) according to Mathews (1977) and Constantino (2002). Voucher samples were deposited on Isoptera Collection at Laboratório de Interações Ecológicas in the Universidade Federal de Sergipe (UFS). All collection was carried out with permission of MMA/ICMBio (SISBIO \#42254-1).

\subsubsection{Habitat structure}

To examine the edge effect of habitat fragmentation on habitat structure, soil litter biomass, number and size of trees were measured. Soil litter biomass was used as a surrogate of habitat structure in the quadrants while the number and size of trees were used as a surrogate of habitat structure in the transects.

For soil litter biomass, all litter from soil surface in the centre $(0.5 \mathrm{~m} \times 0.5 \mathrm{~m})$ of each quadrant were collected, taken to the laboratory and oven dried $\left(60^{\circ} \mathrm{C}\right)$ during four days. Then, the weight of final samples was measured using a precision balance.

The number and size of trees were measured along all transects. The diameter at breast height (DBH) was used as a surrogate of the size of trees. Termites are more frequently found on large as opposed to small trees (Araújo et al.,
2010), thus, the number and size of trees were measured only in trees with $\mathrm{DBH} \geq 10$.

\subsection{Data analysis}

To inspect the edge effect of habitat fragmentation on termite community and habitat structure, data were analyzed with linear-mixed models using ' $n l m e$ ' package on R statistical software (R Development Core Team, 2015). Fragment size (ha) and sampling location (forest edge $v s$. forest interior) were treated as fixed effects. Site (i.e. fragment identity) was included as a random factor to account the non-independence of forest edge and interior in the same fragment.

To inspect the edge effect of habitat fragmentation on termite species composition between forest edge and interior of fragments, data were analysed with Permutacional Multivariate Analysis of Variance (PERMANOVA) using 'PERMANOVA+' package on Primer v.6 software (PRIMER-E Ltd, Plymounth, UK; Clarke and Gorley, 2006). PERMANOVA was performed using the Jaccard dissimilarity Index and multiple paired comparisons with 999 permutations. To check which process (turnover or nesting) determines changes in the termite species composition between forest edge and forest interior as well as among fragments, we performed the partitioning of $\beta$ diversity $\left(\beta_{\mathrm{JAC}}\right)$ using "betapart” on R software (R Development Core Team, 2015). Partitioning of $\beta$ diversity $\left(\beta_{\mathrm{JAC}}\right)$ in turnover $\left(\beta_{\mathrm{JTU}}\right)$ and/or nesting $\left(\beta_{\mathrm{JNE}}\right)$ was performed using the Jaccard dissimilarity Index as proposed by Baselga and Orme (2012).

\section{Results}

\subsection{Termite community}

A total of 432 termite records was sampled (227 on the forest edge and 205 on the forest interior), including 119 active nests ( 70 on the forest edge and 49 in the forest interior) and 313 of termite activity in the sampled area (157 on the forest edge and 156 in the forest interior). A total of 32 termite species was collected, in which 23 species were sampled on the forest edge and 20 on the forest interior of fragments (see Table 2).

The termite richness, abundance and their activity in the sampled area did not differ with fragment size as well as between forest edge and interior (see Table 3 ).

\subsection{Habitat structure}

Soil litter biomass, number and size (DBH) of trees did not differ with fragment size as well as between forest edge and interior (see Table 4).

\subsection{Effect of habitat structure on termite community}

Termite species richness and activity showed no significant relationship with soil litter biomass (richness: $F_{[1,41]}=0.18, P=0.66$; activity in the sampled area: $\left.F_{[1,41]}=0.70, P=0.40\right)$. Termite abundance also showed no significant relationship with neither number nor size of trees (number of trees: $F_{[1,23]}=1.76, P=0.19$; DBH: $\left.F_{[1,23]}=0.38, P=0.54\right)$. 
Table 2. Termite (morpho) species with respective subfamily and abundance recorded in the quadrants and transects at forest edge and interior of fragments in Brazilian Atlantic Rainforest, Sergipe, Nourtheastern Brazil (2013/2014).

\begin{tabular}{|c|c|c|c|c|}
\hline \multirow{2}{*}{ Family/ Subfamily } & \multirow{2}{*}{ Species/ morphospecies } & \multicolumn{2}{|c|}{ Locality } & \multirow{2}{*}{ Total } \\
\hline & & Edge & Interior & \\
\hline Kalotermitidae & Paraneotermes sp. & 1 & & 1 \\
\hline \multirow[t]{2}{*}{ Rhinotermitidae } & Heterotermes longiceps (Snyder, 1924) & 18 & 19 & 37 \\
\hline & Dolicorhinotermes longilabius (Emerson, 1925) & & 2 & 2 \\
\hline \multicolumn{5}{|l|}{ Termitidae } \\
\hline \multirow[t]{8}{*}{ Apicotermitinae } & Anoplotermes sp. 1 & & 3 & 3 \\
\hline & Anoplotermes sp. 2 & 5 & 2 & 7 \\
\hline & Anoplotermes sp. 3 & 1 & 2 & 3 \\
\hline & Anoplotermes sp. 4 & 2 & 1 & 3 \\
\hline & Anoplotermes sp. 5 & & 2 & 2 \\
\hline & Anoplotermes sp. 6 & & 2 & 2 \\
\hline & Anoplotermes sp. 7 & & 1 & 1 \\
\hline & Ruptitermes xanthochiton Mathews, 1977 & 1 & 1 & 2 \\
\hline \multirow[t]{2}{*}{ Syntermitinae } & Silvestritermes euamignathus Silvestri, 1901 & 2 & & 2 \\
\hline & $\begin{array}{l}\text { Embiratermes brevinasus Emerson \& Banks } \\
1957\end{array}$ & & 3 & 3 \\
\hline \multirow[t]{8}{*}{ Nasutitermitinae } & Constrictotermes cyphergaster (Silvestri, 1901) & 5 & & 5 \\
\hline & Diversitermes diversimilis (Silvestri, 1901) & & 3 & 3 \\
\hline & Nasutitermes sp. & 11 & & 11 \\
\hline & Nasutitermes cf. minor & 10 & 10 & 20 \\
\hline & Nasutitermes corniger & 8 & 2 & 10 \\
\hline & Nasutitermes cf. macrocephalus & 5 & 2 & 7 \\
\hline & Nasutitermes cf. kemneri & 8 & & 8 \\
\hline & Velocitermes heteropterus (Silvestri, 1901) & 19 & & 19 \\
\hline \multirow[t]{11}{*}{ Termitinae } & Amitermes sp. & 21 & 8 & 29 \\
\hline & Cylindrotermes sp. & 5 & & 5 \\
\hline & $\begin{array}{l}\text { Cylindrotermes sapiranga } \\
\text { Rocha \& Cancello, } 2007\end{array}$ & 2 & & 2 \\
\hline & Dihoplotermes inusitatus Araujo, 1961 & 2 & & 2 \\
\hline & Inquilinitermes microcerus Silvestri, 1901 & 1 & & 1 \\
\hline & Microcerotermes strunckii (Soerensen, 1884) & 84 & 124 & 208 \\
\hline & Neocapritermes opacus (Hagen, 1858) & & 1 & 1 \\
\hline & Termes sp. & 14 & 16 & 30 \\
\hline & Planicapritermes sp. & 1 & & 1 \\
\hline & Workers not identified 1 & & 1 & 1 \\
\hline & Workers not identified 2 & 1 & & 1 \\
\hline $\begin{array}{l}\text { Total registers } \\
\text { number }\end{array}$ & & 227 & 205 & 432 \\
\hline Richness & & 23 & 20 & 32 \\
\hline
\end{tabular}

\subsection{Partitioning of $\beta$ diversity between edge and interior}

Termite species composition differed between forest edge and interior (PERMANOVA, pseudo $\mathrm{F}=2.45, P=0.002$ ). Post-hoc tests showed that significant difference in termite species composition occurred between forest edge and interior of the bigger fragments ( $\mathrm{MC}$ and $\mathrm{MJ}$ ) sampled (MC, $\mathrm{t}=1.4579, P=0.031 ; \mathrm{MJ}, \mathrm{t}=1.6459, P=0.001)$. In the smaller fragment (MCR) no significantly difference was observed in termite species composition between forest edge and interior $(\mathrm{t}=1.2732, \mathrm{p}=0.174)$. 
Table 3. Details of linear mixed models examining the relationship between fragment size, locality (forest edge and interior) and termite community structure (i.e. (i) termite richness, (ii) termite activity and (iii) termite abundance) in Brazilian Atlantic Rainforest. Locality (forest edge and interior) and fragment size were modelled as fixed factor whereas site (fragment identity) and locality (forest edge and interior) nested within site, as random effects.

\begin{tabular}{|c|c|c|c|c|c|}
\hline Term & d.f. & $F$ & $P$ & StDev & Residuals \\
\hline \multicolumn{6}{|l|}{ Termite richness } \\
\hline Intercept & 1,42 & 200.74 & $<.0001$ & & \\
\hline Fragment size & 1,1 & 0.80 & 0.535 & & \\
\hline Locality (Edge/Interior) & 1,2 & 0.39 & 0.595 & & \\
\hline \multicolumn{6}{|l|}{ Randon effects } \\
\hline Fragment identity & & & & $3.15 \mathrm{e}-05$ & \\
\hline Locality (Edge/Interior) & & & & $4.97 \mathrm{e}-06$ & 1.33 \\
\hline \multicolumn{6}{|l|}{ Termite activity } \\
\hline Intercept & 1,42 & 30.177 & $<.0001$ & & \\
\hline Fragment size & 1,1 & 0.72 & 0.551 & & \\
\hline Locality (Edge/Interior) & 1,2 & 0.06 & 0.816 & & \\
\hline \multicolumn{6}{|l|}{ Randon effects } \\
\hline Fragment identity & & & & 0.94 & \\
\hline Locality (Edge/Interior) & & & & 0.001 & 2.11 \\
\hline \multicolumn{6}{|l|}{ Termite abundance } \\
\hline Intercept & 1,42 & 70.946 & $<.0001$ & & \\
\hline Fragment size & 1,1 & 0.24 & 0.709 & & \\
\hline Locality (Edge/Interior) & 1,2 & 1.16 & 0.393 & & \\
\hline \multicolumn{6}{|l|}{ Randon effects } \\
\hline Fragment identity & & & & $3.31 \mathrm{e}-05$ & \\
\hline Locality (Edge/Interior) & & & & $5.37 \mathrm{e}-06$ & 1.60 \\
\hline
\end{tabular}

Table 4. Details of linear mixed models examining the relationship between fragment size, locality (forest edge and interior) and habitat structure (i.e. (i) soil litter biomass, (ii) number of trees and (iii) size of tree [DBH]) in Brazilian Atlantic rain forest. Locality (forest edge and interior) and fragment size were modelled as fixed factor whereas site (fragment identity) and locality (forest edge and interior) nested within site, as random effects.

\begin{tabular}{|c|c|c|c|c|c|}
\hline Term & $d . f$ & $F$ & $P$ & StDev & Residuals \\
\hline \multicolumn{6}{|l|}{ Soil litter biomass } \\
\hline Intercept & 1,42 & 114.44 & $<.0001$ & & \\
\hline Fragment size & 1,1 & 2.95 & 0.335 & & \\
\hline Locality (Edge/Interior) & 1,2 & 5.12 & 0.151 & & \\
\hline \multicolumn{6}{|l|}{ Randon effects } \\
\hline Fragment identity & & & & 30.878 & \\
\hline Locality (Edge/Interior) & & & & 61.049 & 61.45 \\
\hline \multicolumn{6}{|l|}{ Number of trees } \\
\hline Intercept & 1,42 & 234.23 & $<.0001$ & & \\
\hline Fragment size & 1,1 & 0.002 & 0.968 & & \\
\hline Locality (Edge/Interior) & 1,2 & 0.746 & 0.478 & & \\
\hline \multicolumn{6}{|l|}{ Randon effects } \\
\hline Fragment identity & & & & 0.0001 & \\
\hline Locality (Edge/Interior) & & & & 2.188 & 5.44 \\
\hline \multicolumn{6}{|l|}{ Size of trees $(\mathrm{DBH})$} \\
\hline Intercept & 1,42 & 72.24 & $<.0001$ & & \\
\hline Fragment size & 1,1 & 0.39 & 0.642 & & \\
\hline Locality (Edge/Interior) & 1,2 & 0.004 & 0.951 & & \\
\hline \multicolumn{6}{|l|}{ Randon effects } \\
\hline Fragment identity & & & & 3.146 & \\
\hline Locality (Edge/Interior) & & & & 0.0006 & 14.80 \\
\hline
\end{tabular}


Considering all sampled fragments, $\beta$ diversity between forest edge and interior $\left(\beta_{\mathrm{JAC}}=0.67\right.$; Figure 1$)$ showed to be more affected by species replacement (i.e. turnover; $\beta_{\mathrm{JTU}}=0.61$ ) than species loss (i.e. nestedness; $\beta_{\mathrm{JNE}}=0.06$ ). High $\beta$ diversity was verified by analyzing the variance among edge sites $\left(\beta_{\mathrm{JAC}}=0.96\right)$ and forest interior sites $\left(\beta_{\mathrm{JAC}}=0.95\right)$ of different fragments sampled, indicating high differences in termite community composition between fragments. In both cases, the partition of $\beta$ diversity showed greater species replacement effect (Forest edge: $\beta_{\mathrm{JTU}}=0.94$; Forest interior: $\beta_{\mathrm{JTU}}=0.93$ ) than species loss effect (Forest edge: $\beta_{\mathrm{JNE}}=0.02$; Forest interior: $\left.\beta_{\mathrm{JNE}}=0.02\right)$.

\section{Discussion}

Termite communities have been reported to be affected by resource availability and structural aspects of forests. In the present study, resource availability (soil litter biomass) and vegetational structure (number and size of trees) did not significantly differ between forest edge and interior of studied fragments (see Table 4), which can somehow explain no edge effects on termite's activity in the sampled areas as well as in the termite abundance and richness (see Table 3). However, termite species composition differed between forest edge and interior as well as in the fragments sampled.

The fact that termite activity has not changed between forest edge and interior (Table 3) suggests that at least part of ecosystem services resulting from physical processes of termite activity (e.g. construction of tunnels and galleries) may be preserved in the fragments studied here. However, it does not exclude the possibility that activity in the cycling of organic matter is somehow compromised.

The presence of termite galleries in trees of Brazilian Atlantic Rainforest has been reported to be related to large trees (Gonçalves et al., 2005; Araújo et al., 2010). Accordingly, denser canopies in forest interior seem to support a higher termite mound abundance compared to forest edge on Nepal (Axelsson and Andersson, 2012). Thus, the absence of variation in the vegetation structure (number and size of trees) between forest edge and interior observed here probably contributes to the lack of effect on availability of nesting sites for arboreal species, such

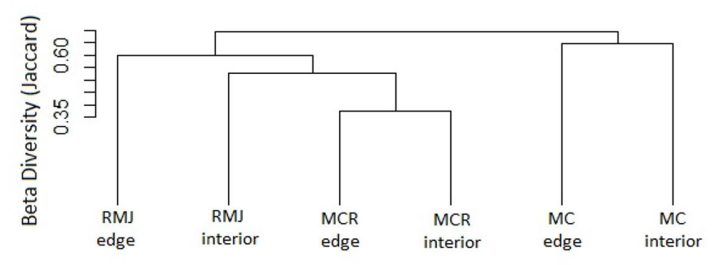

Figure 1. Dendogram showing pairwise comparison of $\beta$ diversity (Jaccard) and its components among their localities (forest edge and interior) and fragments identity. $\mathrm{MJ}=$ Mata do Junco, MCR= Mata do Campus Rural, MC = Mata do Crasto. Sergipe, Brazil. as Microcerotermes strunckii (Termitidae: Termitinae) the dominant species in our study (see Table 2).

Our results showed no response of termite richness to habitat fragmentation (Table 3), as already showed in other studies (e.g. Davies, 2002; Florencio and Diehl, 2006). Termites have been shown to modulate their foraging according to food resource availability (Araújo et al., 2011). Under low resource availability, termite workers build more and longer tunnels which can increase the chances of records of termites in sites with poor resource availability. This strategy can explain negative and no relationship between species richness (and/or abundance) and resources availability. The increment of soil litter biomass has been shown to decrease termite richness and abundance in a Brazilian Atlantic Rainforest (Araújo et al., 2007). In turn, no effect has been observed in Brazilian "Cerrado" (Oliveira et al., 2013).

Our results suggest that termite communities in forest edge and interior are over changes in the species composition. Under edge effect, changes in the microclimatic conditions can modify the availability of niches promoting maintenance of different species composition between sites. Distinct levels of tolerance in relation to temperature and humidity is commonly reported for termite species. Temperature has been considered a determinant factor for termite's occurrence at local, regional or global scale (Davies et al., 2003; Palin et al., 2011). Along a latitudinal gradient in the Brazilian Atlantic Rainforest, temperature is the main driver of termite species composition and richness (Cancello et al., 2014). Termite species feed along humus gradients (Donovan et al., 2001), which can indicate that although all detritivores, an increase of termite richness may favour larger niche complementarity, and consequently greater stability of communities. Therefore, the impairment in the functioning of ecosystem services due to loss of whole functional groups (Dirzo et al., 2014), can also be plausible to occurs in cases of species turnover process (i.e. substitution of species). On a local scale, increment of temperature and humidity may also affect negatively the humivorous guild due to greater sensitivity to desiccation (see Eggleton et al., 1994, 2002; Davies, 2002; Jones et al., 2003; Luke et al., 2014).

Changes in the termite species composition were evident not only forest edge and interior, but also among fragments studied. Species turnover seems to be the main process for variation in the termite species composition between forest edge and interior in the larger fragments (MC and MJ). On the other hand, no effect on the termite species composition was observed in the smaller fragment. Alterations in environmental quality by habitat fragmentation are stronger in small fragments in relation to large ones. So, no effect on termite species composition in the smaller fragment (MCR) can be explained by the fact that as much as the fragment becomes smaller, abiotic conditions are more similar between forest edge and interior. In cases of a prevalence of turnover process, the conservation strategies should be based on selection of several different 
sites instead of few rich sites (e.g. under nesting process) as suggested by Baselga (2010).

The comprehension of mechanisms promoting the increment of $\beta$ diversity can help the conservation strategies, especially in the studied area (Atlantic Rainforest, Northeastern, Brazil). Nowadays, Brazilian Atlantic Rainforest presents only around $2 \%$ of its original area (Silva and Tabarelli, 2000 ), in which $90 \%$ of those remaining areas present less than $50 \mathrm{~h}$ in size. In this biome, the preservation of termite diversity can play a "key role" in the dynamics and stability of communities. Termite species are known to modulate the soil structure and quality, as well to promote the maintenance of several species from different taxa, contributing indirectly to increase the local diversity (Lee and Wood, 1971; Whitford, 1996; Moreira et al., 2009; Beaudrot et al., 2011). Thus, conservation of termite species can increase not only the ecosystem services by these important ecological group as well as increase the local diversity of invertebrates and plants.

In conclusion, our results showed the importance of preserving all remaining areas, including smaller ones to maintain the diversity and functioning of these Atlantic Rainforest ecosystems. In addition, our study contributes to the scarce knowledge about the edge effects on termite communities.

\section{Acknowledgements}

We are grateful to the MIP Lab. and to L. Bacci for help in field work, F. A. Schmidt for suggestions and to the staff reserves to logistic support. Brazilian National Research Council (CNPq) support A. P. A. Araújo (484823/20132). P. F. Cristaldo is support by $\mathrm{CNPq} / \mathrm{FAPITEC}-\mathrm{SE}$ (302246/2014-2). C.S. Almeida and N.G. Cruz are supported by CAPES grants. E.J.M. Ribeiro is supported by CNPq undergraduate grant.

\section{References}

ARAÚJO, A.P.A., ARAÚJO, F.S. and SOUZA, O., 2011. Resource suitability affecting foraging area extension in termites (Insecta: Isoptera). Sociobiology, vol. 57, pp. 271-283.

ARAÚJO, A.P.A., GABIALTI, C. and SOUZA, O., 2007. Neotropical termite species (Isoptera) richness declining as resource amount rises: food or enemy-free space constraints? Sociobiology, vol. 49, pp. 93-106.

ARAÚJO, F.S., ARAÚJO, A.P.A., SILVA-JÚNIOR, W.M., MEIRA-NETO, J.A. and SOUZA, O., 2010. Bottom-up effects on selection of trees by termites (Insecta: Isoptera). Sociobiology, vol. 55, pp. 725-733.

AXELSSON, E.P. and ANDERSSON, J., 2012. A case study of termite mound occurrence in relation to forest edges and canopy cover within the Barandabhar forest corridor in Nepal. Int $J$ Biodivers Conserv, vol. 4, pp. 633-641.

BASELGA, A. and ORME, C.D.L., 2012. Betapart: a R package for the study of beta diversity. Methods in Ecology and Evolution, vol. 3, no. 5, pp. 808-812. http://dx.doi.org/10.1111/j.2041210X.2012.00224.x.
BASELGA, A., 2010. Partitioning the turnover and nestedness components of beta diversity. Global Ecology and Biogeography, vol. 19, no. 1, pp. 134-143. http://dx.doi.org/10.1111/j.14668238.2009.00490.x

BEAUDROT, L., DU, Y., RAHMAN KASSIM, A., REJMÁNEK, M. and HARRISON, R.D., 2011. Do epigeal termite mounds increase the diversity of plant habitats in a tropical rain forest in peninsular Malaysia? PLoS One, vol. 6, no. 5, pp. e19777. http:// dx.doi.org/10.1371/journal.pone.0019777. PMid:21625558.

BIGNELL, D.E. and EGGLETON, P., 2000. Termites in ecosystems. In: T. ABE, D.E. BIGNELL and M. HIGASHI, eds. Termites: evolution, sociality, symbioses, ecology. Dordrecht: Kluwer Academic Publishers, pp. 363-387.

CANCELLO, E.M., SILVA, R.R., VASCONCELLOS, A., REIS, Y.T. and OLIVEIRA, L.M., 2014. Latitudinal variation in termite species richness and abundance along the Brazilian Atlantic Forest Hotspot. Biotropica, vol. 46, no. 4, pp. 441-450. http://dx.doi. org/10.1111/btp.12120.

CLARKE, K.R. and GORLEY, R.N., 2006. PRIMER v6: user manual/tutorial. United Kingdom: PRIMER-E.

CONSTANTINO, R., 2002. An illustrated key to Neotropical termite genera (Insecta: Isoptera) based primarily on soldiers. Zootaxa, vol. 67, pp. 1-40.

DAMBROS, C.S., SILVA, V.N.V., AZEVEDO, R. and MORAIS, W., 2013. Road-associated edge effects in Amazonia change termite community composition by modifying environmental conditions. J Nat Conserv, vol. 21, no. 5, pp. 279-285. http:// dx.doi.org/10.1016/j.jnc.2013.02.003.

DAVIES, R.G., 2002. Feeding group responses of a Neotropical termite assemblage to rain forest fragmentation. Oecologia, vol. 133, no. 2, pp. 233-242. http://dx.doi.org/10.1007/s00442-002-1011-8.

DAVIES, R.G., HERNÁNDEZ, L.M., EGGLETON, P., DIDHAM, R.K., FAGAN, L.L. and WINCHESTER, N.N., 2003. Environmental and spatial influences upon species composition of a termite assemblages across neotropical forest islands. Journal of Tropical Ecology, vol. 19, no. 5, pp. 509-524. http://dx.doi.org/10.1017/ S0266467403003560.

DIRZO, R., YOUNG, H.S., GALETTI, M., CEBALLOS, G., ISAAC, N.J. and COLLEN, B., 2014. Defaunation in the Anthropocene. Science, vol. 345, no. 6195, pp. 401-406. http:// dx.doi.org/10.1126/science.1251817. PMid:25061202.

DONOVAN, S., EGGLETON, P. and BIGNELL, D.E., 2001. Gut content analysis and a new feeding group classification termites. Ecological Entomology, vol. 26, no. 4, pp. 356-366. http://dx.doi. org/10.1046/j.1365-2311.2001.00342.x.

EGGLETON, P., BIGNELL, D.E., HAUSER, S., DIBOG, L., NORGROVE, L. and MADONG, B., 2002. Termite diversity across an anthropogenic disturbance gradient in the humid forest zone of West Africa. Agriculture, Ecosystems \& Environment, vol. 90, no. 2, pp. 189-202. http://dx.doi.org/10.1016/S01678809(01)00206-7.

EGGLETON, P., WILLIAMS, P.H. and GASTON, K., 1994. Explaining global termite diversity: productivity or history? Biodiversity and Conservation, vol. 3, no. 4, pp. 318-330. http:// dx.doi.org/10.1007/BF00056505.

FLORENCIO, D.F. and DIEHL, E., 2006. Termitofauna (Insecta, Isoptera) em remanescentes de floresta estacional semidecidual. Revista Brasileira de Entomologia, vol. 50, no. 4, pp. 505-511. http://dx.doi.org/10.1590/S0085-56262006000400011. 
GONÇALVES, T.T., DESOUZA, O., REIS-JÚNIOR, R. and RIBEIRO, S.P., 2005. Effect of tree size and growth form on the presence and activity of arboreal termites (Insecta: Isoptera) in the Atlantic rain forest. Sociobiology, vol. 46, pp. 421-432.

HOLT, J.A. and LEPAGE, M., 2000. Termites and soil properties. In: T. ABE, D.E. BIGNELL and M. HIGASHI, eds. Termites: evolution, sociality, symbiosis, ecology. Dordrecht: Kluwer Academic Publishers, pp. 389-407. http://dx.doi.org/10.1007/97894-017-3223-9_18.

JONES, C.G., LAWTON, J.H. and SHACHAK, M., 1994. Organisms as ecosystem engineers. Oikos, vol. 69, no. 3, pp. 373-386. http://dx.doi.org/10.2307/3545850.

JONES, D.T. and EGGLETON, P., 2000. Sampling termite assemblages in tropical forests: testing a rapid biodiversity assessment protocol. Journal of Applied Ecology, vol. 37, no. 1, pp. 191-203. http://dx.doi.org/10.1046/j.1365-2664.2000.00464.x.

JONES, D.T., SUSILO, F.X., BIGNELL, D.E., HARDIWINOTO, S., GILLISON, A.N. and EGGLETON, P., 2003. Termite assemblage collapse along a land-use intensification gradient in lowland central Sumatra, Indonesia. Journal of Applied Ecology, vol. 40, no. 2, pp. 380-391. http://dx.doi.org/10.1046/j.1365-2664.2003.00794.x.

KLEIN, B.C., 1989. Effects of forest fragmentation on dung and carrion beetle communities in central Amazonia. Ecology, vol. 70, no. 6, pp. 1715-1725. http://dx.doi.org/10.2307/1938106.

LAURANCE, S.G., 2004. Responses of understory rain forest birds to road edges in central Amazonia. Ecological Applications, vol. 14, no. 5, pp. 1344-1357. http://dx.doi.org/10.1890/03-5194.

LEE, K.E. and WOOD, T.G., 1971. Termites and soil. London: Academic

LEIDNER, A.K., HADDAD, N.M. and LOVEJOY, T.E., 2010. Does Tropical forest fragmentation increase long-term variability of butterfly communities? PLoS One, vol. 5, no. 3, pp. e9534. http://dx.doi.org/10.1371/journal.pone.0009534. PMid:20224772.

LUKE, S.H., FAYLE, T.M., EGGLETON, P., TURNER, E.C. and DAVIES, R.G., 2014. Functional structure of ant and termite assemblages in old growth forest, logged forest and oil palm plantation in Malaysian Borneo. Biodiversity and Conservation, vol. 23, no. 11, pp. 2817-2832. http://dx.doi.org/10.1007/s10531014-0750-2.

MACIEL, M.N.M., WATZLAWICK, L.F., SCHOENINGER, E.R. and YAMAJI, F.M., 2003. Classificação ecológica das espécies arbóreas. Revista Acadêmica: Ciências Agrárias e Ambientais, vol. 1, pp. 69-78.

MATHEWS, A.G.A., 1977. Studies on termites from the Mato Grosso State, Brazil. Rio de Janeiro: Academia Brasileira de Ciências.

MOREIRA, L.A., FENOLIO, D.B., SILVA, H.L.R. and SILVA-JR, N.J., 2009. A preliminary list of the Hepertofauna from termite mounds of the Cerrado in the upper Tocantins river valet. Papéis Avulsos de Zoologia, vol. 49, no. 15, pp. 183-189.

MYERS, N., MITTERMEIER, R.A., MITTERMEIER, C.G., FONSECA, G.A. and KENT, J., 2000. Biodiversity hotspots for conservation priorities. Nature, vol. 403, no. 6772, pp. 853-858. http://dx.doi.org/10.1038/35002501. PMid:10706275.
OLIVEIRA, D., CARRIJO, T. and BRANDÃO, D., 2013. Species composition of Termites (Isoptera) in different Cerrado vegetation Physiognomies. Sociobiology, vol. 60, no. 2, pp. 190-197. http:// dx.doi.org/10.13102/sociobiology.v60i2.190-197.

PALIN, O.F., EGGLETON, P., MALHI, Y., GIRARDIN, C.A.J., ROZAS-DÁVILA, A. and PARR, C.L., 2011. Termite diversity along an Amazon-Andes elevation gradient, Peru. Biotropica, vol. 43 , no. 100 , pp. 1-8. http://dx.doi.org/10.1111/j.17447429.2010.00650.x

PENIDO, G., RIBEIRO, V. and FORTUNATO, D.S., 2015. Edge effect on post-dispersal artificial seed predation in the southeastern Amazonia, Brazil. Brazilian Journal of Biology = Revista Brasileira de Biologia, vol. 75, no. 2, pp. 347-351. http:// dx.doi.org/10.1590/1519-6984.12813. PMid:26132017.

PINHEIRO, E.R.S., DUARTE, L.S., DIEHL, E. and HARTZ, S.M., 2010. Edge effects on epigeic ant assemblages in a grasslandforest mosaic in southern Brazil. Acta Oecologica, vol. 36, no. 4, pp. 365-371. http://dx.doi.org/10.1016/j.actao.2010.03.004.

PRINGLE, R.M., DOAK, D.F., BRODY, A.K., JOCQUÉ, R. and PALMER, T.M., 2010. Spatial Pattern Enhances Ecosystem Functioning in an African Savanna. PLoS Biology, vol. 8, no. 5, pp. e1000377. http://dx.doi.org/10.1371/journal.pbio.1000377. PMid:20520846.

R DEVELOPMENT CORE TEAM, 2015. $R$ : a Language and Environment for Statistical Computing. Vienna: R Foundation for Statistical Computing.

REDFORD, K.H., 1984. The termitaria of Cornitermes cumulans (Isoptera: Termitidae) and their role in determining a potential keystone species. Biotropica, vol. 16, no. 2, pp. 112-119. http:// dx.doi.org/10.2307/2387842.

RIBEIRO, C.M., METZGER, J.P., MARTENSEN, A.C., PONZONI, F.J. and HIROTA, M.M., 2009. The Brazilian Atlantic Forest: How much is left, and how is the remaining forest distributed? Implications for conservation. Biological Conservation, vol. 142, no. 6, pp. 1141-1153. http://dx.doi.org/10.1016/j.biocon.2009.02.021.

SANTOS, M.J.S., SOUZA, H.T.R. and SOUZA, R.M., 2007. Biomonitoramento através de indicadores ambientais abióticos Mata do Junco (Capela-SE). Scientia Plena, vol. 3, pp. 142-151.

SILVA, J.M.C. and TABARELLI, M., 2000. The species impoverishment and the future flora of the Atlantic Forest of Northeast Brazil. Nature, vol. 404, no. 6773, pp. 72-74. http:// dx.doi.org/10.1038/35003563. PMid:10716443.

SOUZA, O., SCHOEREDER, J.H., BROWN, V. and BIERREGAARD JUNIOR, R., 2001. A theoretical overview of the processes determining species richness in forest fragments. In: R. BIERREGAARD JUNIOR, S. LOVEJOY, R. MESQUITA and C. GASCON, eds. Lessons from Amazonia: the ecology and conservation of a fragmented forest. New York: Yale University Press, pp. 111-121.

SOUZA, O.F. and BROWN, V.K., 1994. Effects of habitat fragmentation on Amazonian termite communities. Journal of Tropical Ecology, vol. 10, no. 02, pp. 197-206. http://dx.doi. org/10.1017/S0266467400007847.

WHITFORD, W.G., 1996. The importance of the biodiversity of soil biota in arid ecosystems. Biodiversity and Conservation, vol. 5, no. 2, pp. 185-195. http://dx.doi.org/10.1007/BF00055829. 